\section{ECONOMICS}

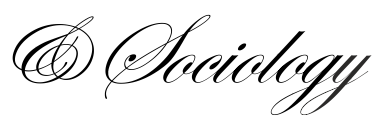

Szostak, M., \& Sułkowski, Ł. (2021). Artist, creator, manager, entrepreneur, leader: How society perceive these identities?. Economics and Sociology, 14(2), 209221. doi:10.14254/2071-789X.2021/14-2/11

\title{
ARTIST, CREATOR, MANAGER, ENTREPRENEUR, LEADER: HOW SOCIETY PERCEIVE THESE IDENTITIES?
}

\author{
Michał Szostak \\ Department of Management and \\ Security, University of Social \\ Sciences, \\ Warsaw, Poland \\ E-mail:mszostak@san.edu.pl \\ ORCID 0000-0002-7774-2964 \\ Lukasz Sułkowski \\ Faculty of Management and Social \\ Communication, Jagiellonian \\ University in Cracow, \\ Cracow, Poland \\ E-mail: \\ lukasz.sulkowski@uj.edu.pl \\ ORCID 0000-0002-1248-2743
}

Received: March, 2020

1st Revision: September, 2020

Accepted: May, 2021

DOI: $10.14254 / 2071-$

789X.2021/14-2/11

JEL Classification: D91, J19, L26, M30, Z11

\begin{abstract}
Because personal identity is one of the key elements constituting an individual, and perception of different type of identities is a key feature in identity work, we think that the research in the area of perception of artists, creators, managers, entrepreneurs, and leaders should bring important conclusions to the understanding of those identities. We ran a literature review and quantitative research among society representatives $(n=160)$. The main findings of our research show that artists, creators, managers, entrepreneurs, and leaders are perceived differentially by society although we can find areas of similarities and important differences. The hypotheses were confirmed using chi-square test of independence dedicated to small samples which don't have a normal distribution $(\mathrm{p}<0.001)$ : H1. Majority of the society does not recognize differences between creativity and artistry; H2. Creativity and entrepreneurship have similar perceptions among society; H3. Leadership and organizing have similar perceptions among society. The results of this research can be used to compare the identity perceived by individuals and the perception of these identities by society.
\end{abstract}

Keywords: identity, perception, creativity, creativeness, artistry, entrepreneurship, organizing, leadership.

\section{Introduction}

Personal identity is one of the key elements constituting an individual. Although external factors, like the social and intellectual background, initial material wealth, or just luck, influence the fate of each person, it is the identity being the driving force behind the entire private and professional life of an individual. It is a natural approach that researches focus on the features of the successful persons in different areas of their activities, to conclude the improvement of education systems and finally the comfort and happiness of life for less talented or less lucky part of the society.

Working on our previous research in the area of artist's identity, creator's identity, manager's identity, and entrepreneur's identity, we found that even the persons who possess 
talent, personal characteristics, and well established professional position in the above areas, have problems with definition who an artist is, who a creative person is, who a manager is, who a leader is, or who an entrepreneur is. These blurred "definitions" of the particular identities led us to separate the complex identities of artists-managers (Szostak \& Sułkowski, 2020a, 2020b, 2021a, 2021b) and artists-entrepreneurs. Besides, while separating the creativity factor among these groups of individuals, we found that even the individuals with highly developed abilities allowing to describe their characteristics have many problems with the distinction between the creative and noncreative artist/manager/entrepreneur/leader.

These conclusions led us to the idea that the comparison of a particular identity and its perception by society could reveal additional values. But, due to the complexity of the problem and the literature gap in the area of perception of these individuals, based on the comparable factors and indicators, we focused on the perception first. Based on the above considerations, we set the following research hypotheses:

H1. Majority of the society does not recognize differences between creativity and artistry.

H2. Creativity and entrepreneurship have similar perceptions among society.

H3. Leadership and organizing have similar perceptions among society.

Firstly, secondary research in the form of reviewing literature and data was conducted. The literature review methodology was based on a qualitative choice of the literature taken from databases: EBSCO, Google Scholar, JSTOR, and Scopus. The methodological approach to the literature review based on an interdisciplinary and multi-paradigm approach taking into account the publications from the areas of art (artist's identity), creativity (creative person's identity), management (manager's identity), entrepreneurship (entrepreneur's identity), and psychology (identity tensions, paradoxical thinking). Secondly, quantitative research was conducted.

\section{Literature review}

Literature shows many types of identities. The basic distinction of identities is about individual and group, e.g.: personal identity (Zambrell, 2016) versus group identity (Vincent \& Kouchaki, 2016), and collective identity, particularly, expressed in human resources identity, which is important for HRM development within the business management (Bilan et al., 2020). If we add the optics of a society or a nation, we can research a social identity (McNeill \& Venter, 2019; Sethi et al., 2012), enterprise ecosystem identity (Okuneviciute Neverauskiene \& Pranskeviciute, 2021), regional and local identity (Devkota et al., 2020; Kostiukevych et al., 2020) and national identity (Grigoryan \& Kotova, 2018; Saavedra Llamas \& Grijalba de la Calle, 2020). Adding the organization optics, we will get an organizational identity (Erat et al., 2020) or identity integration (Tendayi Viki \& Williams, 2014). Other distinction focuses on the area of individual's activities, revealing e.g. a professional identity (Kunrath et al., 2020; Zocche et al., 2018). Adding ethics optics, we can define a moral identity (Gerpott et al., 2019). Looking through a market lens, we will find a brand identity (Szczepaniak, 2018). Taking into consideration a processual approach, we can find a developing identity (Yazar \& Arifoglu, 2012), established identity (Erat et al., 2020), sustainable identity (McNeill \& Venter, 2019), and identity work (Bennett \& Hennekam, 2018; Reedy, 2008). Researchers also found the aspect of the structure of the identity revealing identity construction (Watson, 2009; Zambrell, 2016). Taking into account the issue of interactions between relational identity (Brewer \& Gardner, 1996) or identity regulation or formation (Warhurst, 2011). If we take identity as an organization's asset, we may say about identity management strategies (Grigoryan \& Kotova, 2018), or about a narrative identity (Gray et al., 2015; Sveningsson \& Alvesson, 2003; Wolf, 2019) helping managers to reach 
particular goals. Adding additional dimensions, researchers built particular types of identity, e.g. creative identity (Vincent \& Kouchaki, 2016), or dialogical identity (Masso, 2010). Finally, depending on the complexity, we can have a simple (separate) identity, e.g. manager's identity (Hallier, 2004; Watson, 2009) and artist's identity (Dahlsen, 2015), or a complex identity, e.g. artist-manager's identity (Degot, 2007; Szostak \& Sułkowski, 2020a).

As we see from the above, identity seems to be a multidimensional issue. Due to this fact, its perception is not simple nor unequivocal; the differences both in the areas of identity and perception, lead to the conclusion that the problem may be blurred. Researchers in the area of management investigated this problem on different examples: designers (Kunrath et al., 2020), managers (Erat et al., 2020; Hallier, 2004), actors (Walter, 2015), different national groups (Grigoryan \& Kotova, 2018), mixed-race individuals (Tendayi Viki \& Williams, 2014), children (Yazar \& Arifoglu, 2012), students (Naderi et al., 2009), creative people (Vincent \& Kouchaki, 2016) and many others.

Researchers underline that perception has its limitations influencing the perception process, e.g. perceptive abilities of individuals (Wimschneider \& Brem, 2019), circumstances of the perception itself (Schielke, 2020), or cultural factors determining the way of perception (Saavedra Llamas \& Grijalba de la Calle, 2020). In this situation, due to the complexity of the problem, it is generally impossible to get the simple answer to the question of how a particular identity is perceived. Trying to catalog, how researchers approached the problem of perception of a particular identity, we can conclude that: they limit the issue of the research from general, widely defined identity into a particular type of identity, e.g. identity of nurse manager responsibilities (Baker et al., 2012), identity if project manager (Lutas et al., 2020); they carefully chose the group perceiving the particular identity, e.g. teachers (Kasmaienezhadfard et al., 2015), designers (Kunrath et al., 2020), nurses (Kiran et al., 2019; Raso et al., 2020), consumers of particular products (Horn \& Salvendy, 2009), undergraduate business students (Kohail et al., 2016); or they investigate the problem in comparison of two research groups, e.g. artists and non-artists (Bhattacharya \& Petsche, 2002).

\section{Methodology}

The tool for quantitative research in the form of a questionnaire was developed based on the methodology of Stefan Nowak (2007), consisting of determining the dimensions of the studied phenomenon, and then selecting indicators that allow describing the studied phenomenon. The initial methodological assumption assumed building separate sets of indicators for each of the dimensions. Sets of indicators for individual dimensions began to be built based on the literature on the subject in the field of: artistry (Bayrakci et al., 2009; McHugh, 2015; Szostak, 2020; Walter, 2015; Wilson \& Brown, 2012; Woodward \& Funk, 2010), creativity (Dufour et al., 2020; Gangi, 2018; Lehmann \& Gaskins, 2019; Leso et al., 2017; Szostak \& Sułkowski, 2020; Taleghani, 2012; Zhou et al., 2008), managerial issues (Baker et al., 2012; Bulei et al., 2014; Elstad \& Jansson, 2020; Hallier, 2004; Hatch et al., 2006; Hracs, 2015; Lähdesmäki, 2012; López-Fernández et al., 2018; Lutas et al., 2020), leadership (Adler, 2006; Alvesson \& Blom, 2015; Carroll \& Levy, 2008; Jankurová et al., 2017; Lord \& Brown, 2001; Nikolski, 2015; Postuła \& Majczyk, 2018; Raso et al., 2020; Stuke, 2013; Woodward \& Funk, 2010), and entrepreneurship (Bureau \& Zander, 2014; Cardon et al., 2009; Clarke \& Holt, 2019; Damásio \& Bicacro, 2017; Davidsson, 2006; Enhuber, 2014; Lewis et al., 2016; Postuła \& Majczyk, 2018; Toscher, 2019, 2020). However, the analysis of individual groups of indicators showed that, in principle, each of the indicators selected for individual dimensions can be used to describe each of the examined dimensions. Following this conclusion, a single list of 50 indicators was compiled that was 
applied to all five dimensions examined. Thanks to this, after obtaining the results, it will be possible to compare the results of the same indicators for different dimensions.

The survey was finally divided into four parts. In the first part, we built a list of questions (each question related to one indicator) and divided them into thematic sections on each dimension: artistry, creativity, managerial issues, leadership, and entrepreneurship. All questions were closed, and a five-point Likert scale was built to answer the questions: definitely no, rather no, hard to say, rather yes, definitely yes. In the second part of the study, questions were asked about the relationship of each of the dimensions to the other dimensions. In the third part, the respondents defined their identity concerning each of the dimensions. The fourth part included questions identifying the respondents.

For verification of our hypotheses, we chose the nonparametric chi-square test of independence dedicated to small samples which don't have a normal distribution. We compared the pairs of the observed values with pairs of the expected values for each hypothesis. The p-value of the tests was $<0.001$. Data analysis was performed using the IBM SPSS program and MS Excel. Due to the small size of the sample, we did not conduct complex statistics. This article presents only some of the conclusions from the entire study.

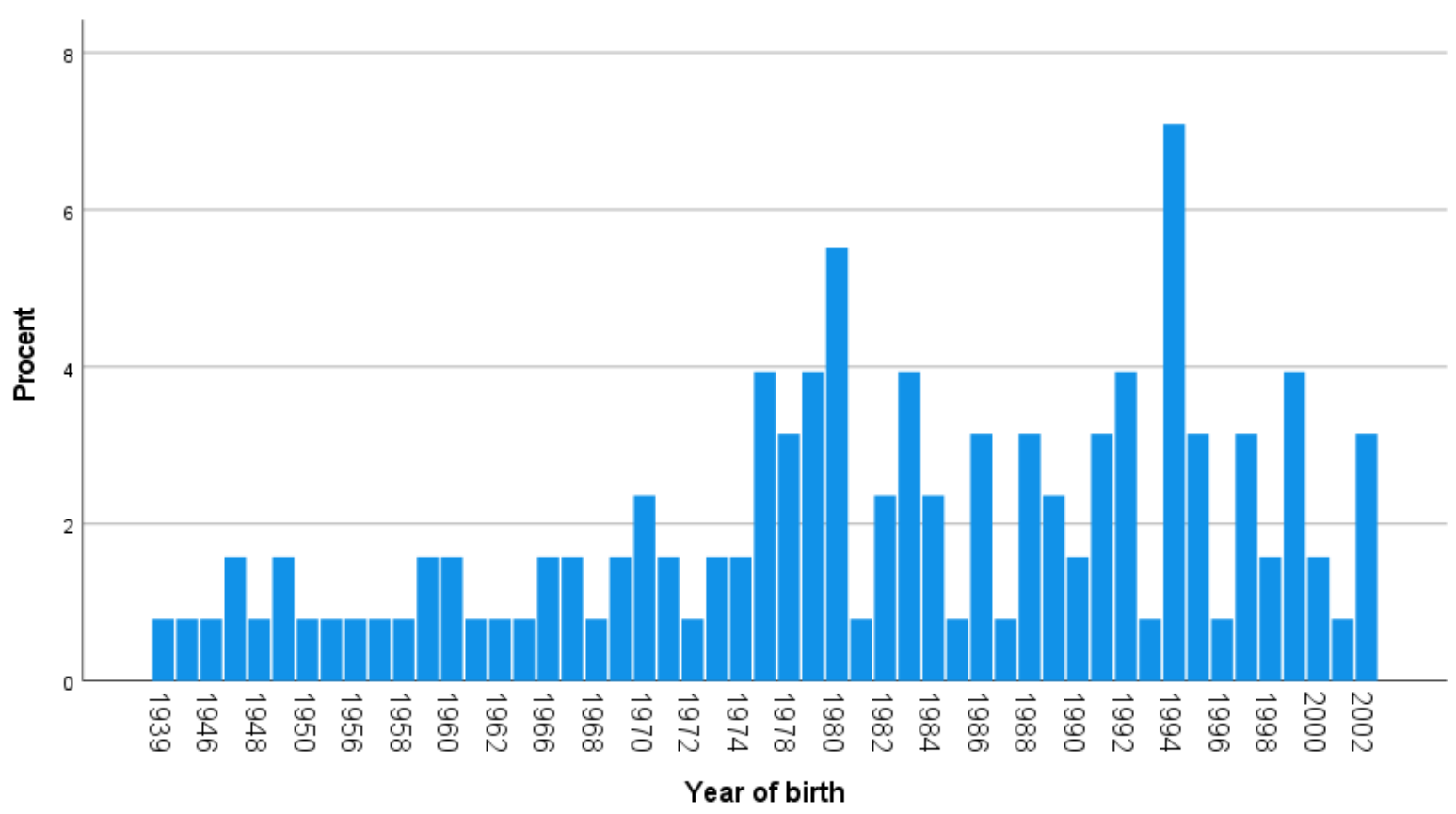

Figure 1. The age of the research participants

Source: Authors' elaboration.

The survey entitled "Perception of creativity, artistry, entrepreneurship, leadership and managerial abilities" lasted 34 days, i.e. from 20th December 2020 to 23rd January 2021. Two identical questionnaires, one in English and the other in Polish, were distributed via direct contact (sending requests to participate in the survey to friends of people) and using indirect public tools (social networks, collective messages to various types of communities); We estimate the number of people who were asked to take part in the study at approx. 2-3 thousand. 879 people were interested in taking part in the survey, which we judge by clicking on the link leading to the survey. The actual participation in the study, consisting of filling in the questionnaire, was attended by 160 people, i.e. $18.2 \%$ of people interested in taking part in the research. The average time spent on filling in the questionnaire was 32 minutes and 23 seconds, and the average age of the respondent was 38 years. Among the respondents: women constituted $42.5 \%$ and men $57.5 \%$; people with higher education (bachelor, master, engineer) 
$64.57 \%$, people with doctoral, postdoctoral, or professor degrees $18.90 \%$, people with secondary education $15.75 \%$. The respondents came from 28 countries, however, because the distribution of this feature was very diverse, we divided the sample into possibly equivalent crops in this respect, i.e.: $74 \%$ developed countries and $26 \%$ developing countries ${ }^{1}$; European countries $71.7 \%$, and non-European countries $28.3 \%$; Poland $49.6 \%$ and other countries $50.4 \%$; post-communist countries $63.8 \%$ and countries with no experience of communism $36.2 \%$.

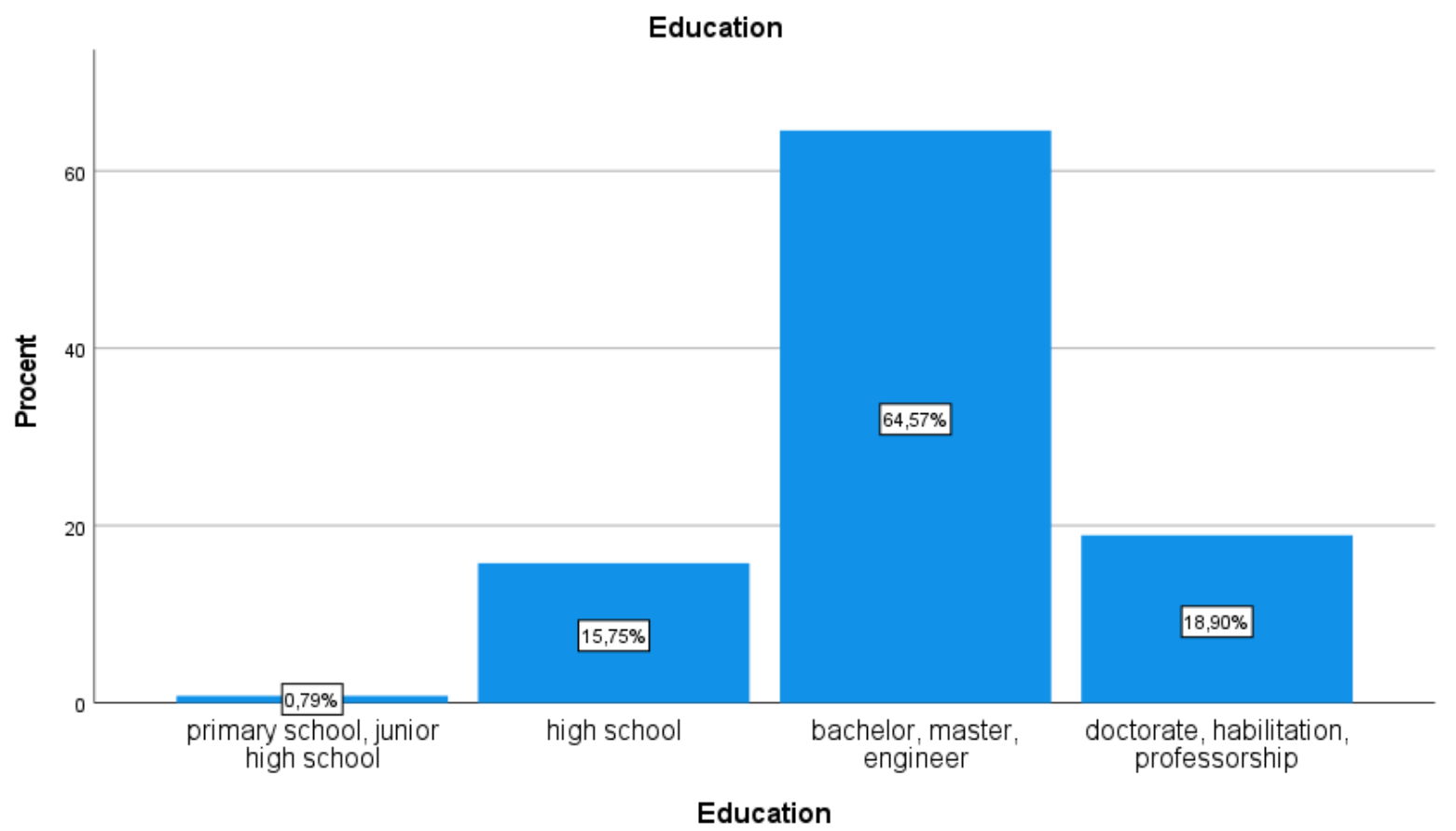

Figure 2. The education of the research participants

Source: Authors' elaboration.

\section{Empirical results and discussion}

Taking into account all respondents, we are able to distinguish clearly the ten features describing each particular researched identity (artist, creator, entrepreneur, leader, manager) in the most unequivocal manner: 1) an artist: passion in action, creativity, talent, selfconfidence, visualization skills and imagination, originality, patience and persistence in achieving goals, sensitivity to Beauty, tendency to be inspired, observation; 2) a creator: passion in action, visualization skills and imagination, self-confidence, talent, courage, patience and persistence in achieving goals, innovation, observation, originality, ability to set goals; 3) an entrepreneur: searching for opportunities, patience and persistence in achieving goals, ability to set goals, responsibility, self-confidence, efficiency, resistance to fails and failures, organizing, courage, focusing on financial profit; 4) a leader: charisma, ability to set goals, ability to resolve conflicts, responsibility, patience and persistence in achieving goals, self-confidence, courage, interpersonal skills (communicativeness, reading emotions, sensitivity to others), resistance to fails and failures, personal characteristics; 5) a manager: efficiency, responsibility, ability to resolve conflicts, ability to set goals, tendency to plan,

\footnotetext{
${ }^{1}$ On the base of Human Development Index: developing countries < 0,71 HDI, developed countries > 0,71 HDI. See: https://worldpopulationreview.com/country-rankings/developing-countries (Accessed on: 28th February 2021).
} 
patience and persistence in achieving goals, ability to analyze, leadership, self-confidence, interpersonal skills (communicativeness, reading emotions, sensitivity to others). The synthetic visualization of these features shows the following tables.

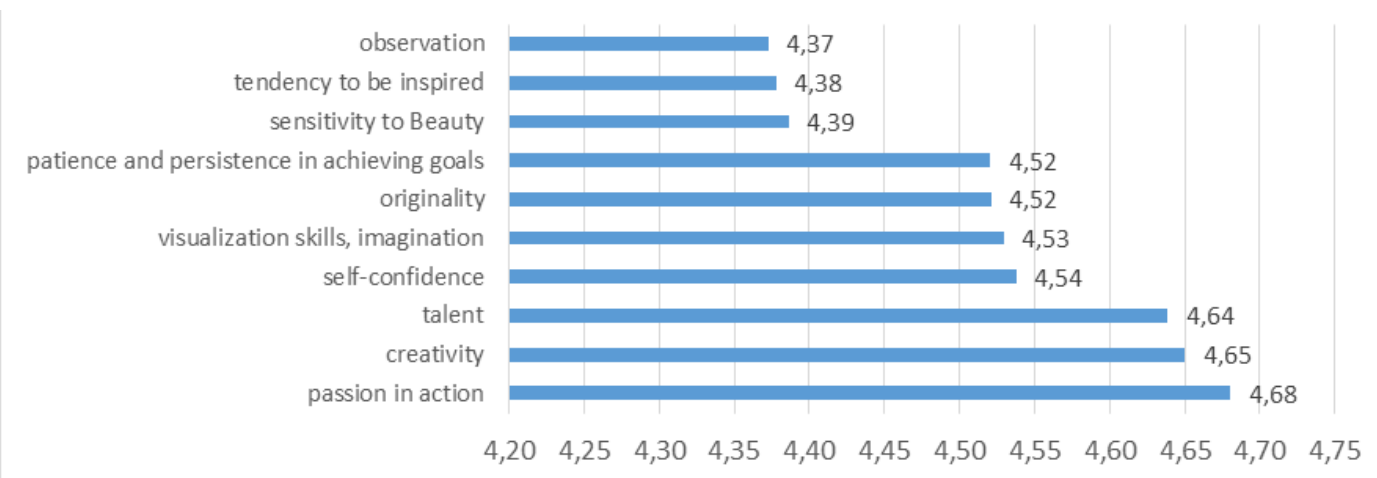

Figure 3. The ten most important features of an artist seen by society Source: Authors' elaboration.

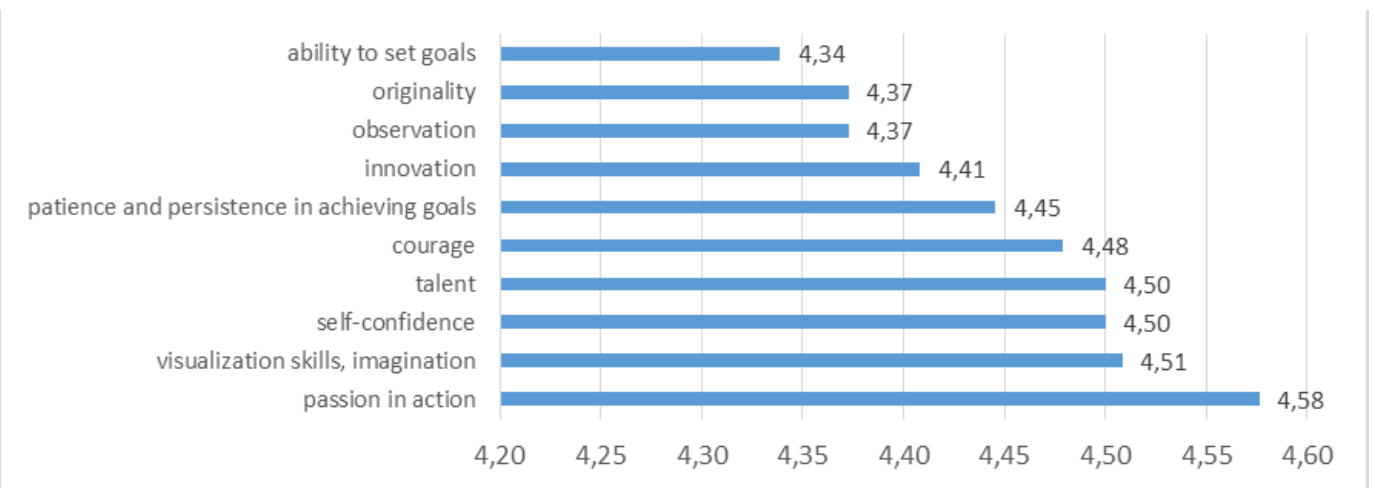

Figure 4 . The ten most important features of a creator seen by society

Source: Authors' elaboration.

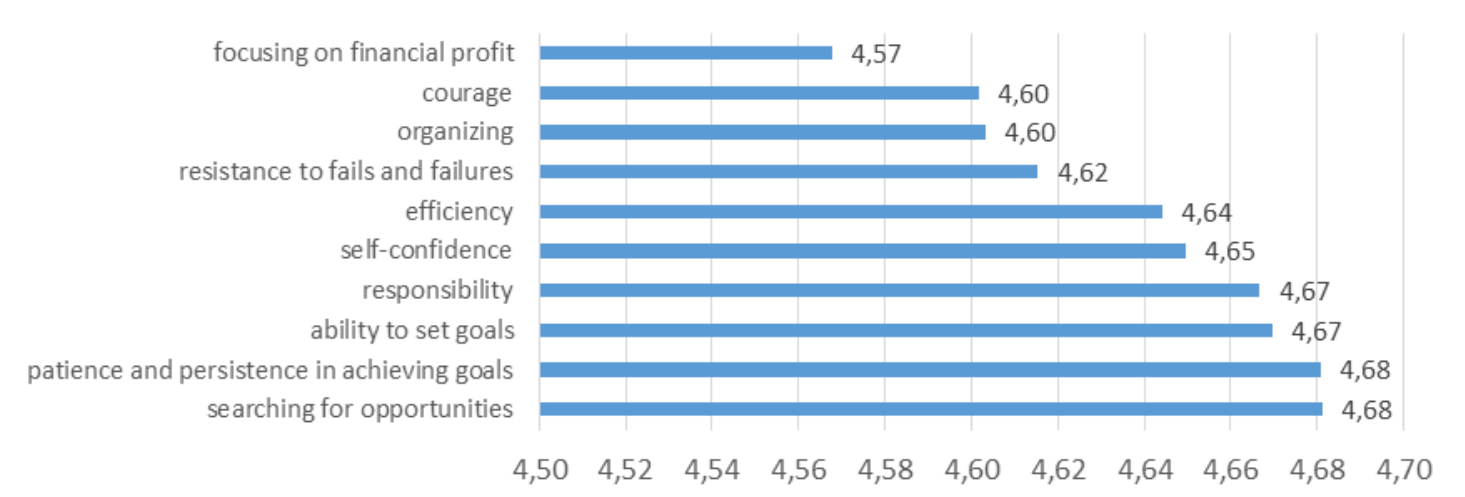

Figure 5. The ten most important features of an entrepreneur seen by society Source: Authors' elaboration. 


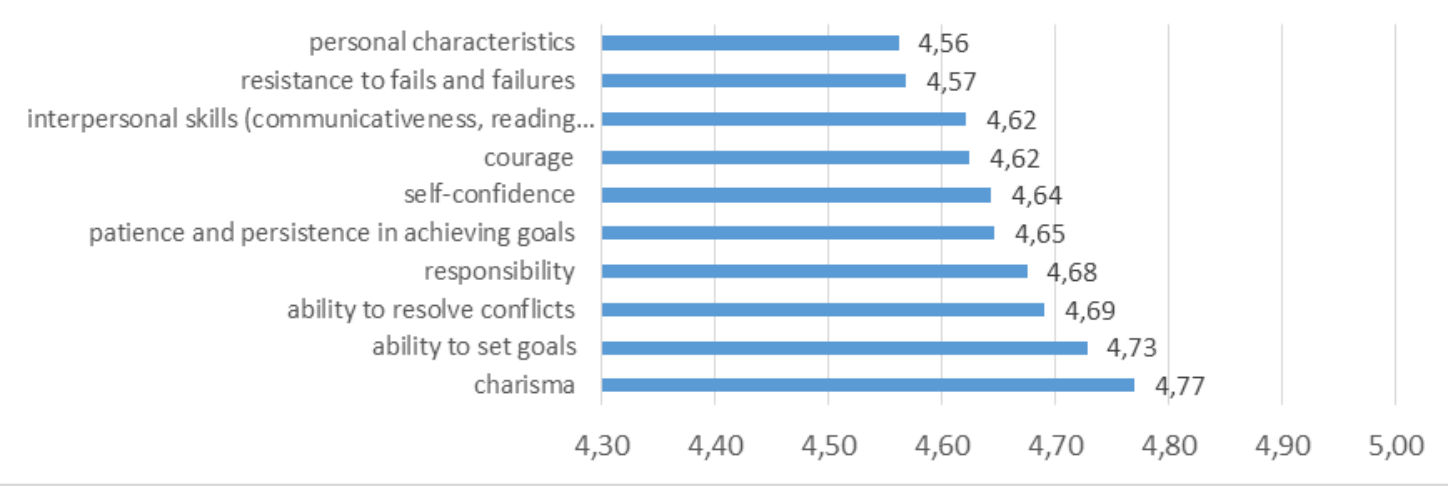

Figure 6 . The ten most important features of a leader seen by society Source: Authors' elaboration.

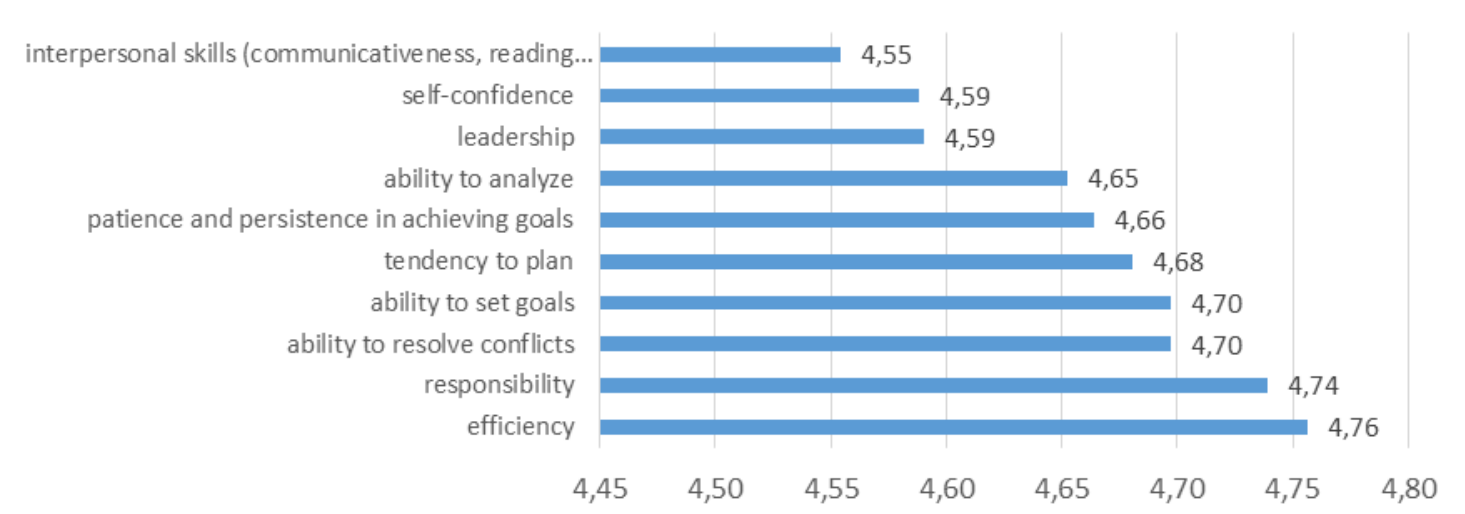

Figure 7. The ten most important features of a manager seen by society Source: Authors' elaboration.

Discussing each research hypothesis separately, we can say that H1 (the majority of society does not recognize differences between creativity and artistry) is verified positively. Our chi-square value $=458.91$. Our df value $=49$. Using the chi-square distribution table, we got the value of 85.3506. This means that our results are statistically significant for the significance level of $\mathrm{p}=0.001$. Although there are slight differences in particular indicators' order and levels of their power, we can find that among the majority (7 of 10) of the most important creativity's and artistry's features are (in alphabetical order): 1) observation, 2) originality, 3) passion in action, 4) patience and persistence in achieving goals, 5) selfconfidence, 6) talent, 7) visualization skills and imagination. On the opposite, among the majority ( 6 of 10) of the least important creativity's and artistry's features are (in alphabetical order): 1) conservatism, 2) disorder, mess, chaos, randomness in action, 3) focusing on financial profit, 4) formal education (schools, studies, courses, training), 5) leadership and 6) tendency to control.

H2 (Creativity and entrepreneurship have similar perceptions among society) is verified positively. Our chi-square value $=461.15$. Our df value $=49$. Using the chi-square distribution table, we got the value of 85.3506. This means that our results are statistically significant for the significance level of $\mathrm{p}=0.001$. Although there are slight differences in particular indicators' order and levels of their power, we can find that among the minority (4 of 10) of the most important creativity's and entrepreneurship's features are (in alphabetical order): 1) ability to set goals, 2) courage, 3) patience and persistence in achieving goals, 4) self-confidence. On the opposite, among the majority (6 of 10) of the least important creativity's and entrepreneurship's features are (in alphabetical order): 1) being guided by 
emotions, 2) being guided by faith and spirituality, 3) conservatism, 4) disorder, mess, chaos, randomness in action, 5) formal education (schools, studies, courses, training), 6) respect for tradition and history.

H3 (Leadership and organizing have similar perceptions among society) is verified positively. Our chi-square value $=489.26$. Our $\mathrm{df}$ value $=49$. Using the chi-square distribution table, we got the value of 85.3506 . This means that our results are statistically significant for the significance level of $\mathrm{p}=0.001$. Although there are slight differences in particular indicators' order and levels of their power, we can find that among the majority (6 of 10) of the most important leader's and manager's features are (in alphabetical order): 1) ability to resolve conflicts, 2) ability to set goals, 3) interpersonal skills (communicativeness, reading emotions, sensitivity to others), 4) patience and persistence in achieving goals, 5) responsibility, 6) self-confidence. On the opposite, among the majority (7 of 10) of the least important leader's and manager's features are (in alphabetical order): 1) artistry, 2) being guided by emotions, 3) being guided by faith and spirituality, 4) conservatism, 5) disorder, mess, chaos, randomness in action, 6) respect for tradition and history, 7) sensitivity to Beauty.

\section{Conclusion}

Among the limitations of the research, we should underline the following elements: 1) The research was run during the deep phase of the COVID-19 pandemic what could influence respondents' views and opinions; 2) The research sample $(n=160)$ was relatively small in comparison to the analyzed problem; 3) Synthetic conclusions can be not widely representative due to complexity of the research problem.

The results of the research can be used by: 1) Individuals (artists, creators, entrepreneurs, leaders, managers) for a) better understanding the different layers of their personality with underlining the issue of complex identity, b) comparison of own identity with the general perception of a particular role; 2) Researchers wanting to investigate the similarities and differences between identity and its perception in area of artistry, creativity, entrepreneurship, leadership, and organizing.

Potential research questions for future qualitative research or the hypothesis for further quantitative research may be: 1) Self-perception of identity may vary drastically from the perception of the identity by the whole society; 2) Self-perception of identity is similar to the perception of the identity by a particular group of society.

\section{References}

Adler, N. J. (2006). The arts \& leadership: Now that we can do anything, what will we do? Academy of Management Learning and Education, 5(4), 486-499. https://doi.org/10.5465/AMLE.2006.23473209

Alvesson, M., \& Blom, M. (2015). Less Followership, Less Leadership? An Inquiry Into the Basic But Seemingly Forgotten Downsides of Leadership.M@n@gement, 18(3), 266282.

Baker, S., Marshburn, D. M., Crickmore, K. D., Rose, S. B., Dutton, K., \& Hudson, P. C. (2012). What do you do? Perception of nurse manager responsibilities. Nursing Management, 43(12), 24-29. https://doi.org/10.1097/01.NUMA.0000422890.99334.21

Bayrakci, B., Forouz, A., Şahin, A. B., Abali, M., \& Aliyeva, G. Z. (2009). Disease painting or painting disease: How does illness and hospitalisation affect children's artistry? Perception, 38(11), 1721-1727. https://doi.org/10.1068/p6138 
Bennett, D., \& Hennekam, S. (2018). Self-authorship and creative industries workers' career decision-making. Human $\quad$ Relations, 71(11), 1454-1477. https://doi.org/10.1177/0018726717747369

Bilan Y., Mishchuk, H., Roshchyk, I., \& Joshi, O. (2020). Hiring and retaining skilled employees in SMEs: problems in human resource practices and links with organizational success. Business: Theory and Practice, 21(2), 780-791. DOI: https://doi.org/10.3846/btp.2020.12750

Bhattacharya, J., \& Petsche, H. (2002). Shadows of artistry: Cortical synchrony during perception and imagery of visual art. Cognitive Brain Research, 13(2), 179-186. https://doi.org/10.1016/S0926-6410(01)00110-0

Brewer, M. B., \& Gardner, W. (1996). Who Is This "We"? Levels of Collective Identity and Self Representations. Journal of Personality and Social Psychology, 71(1), 83-93. https://doi.org/10.1037/0022-3514.71.1.83

Bulei, I., Mihalcioiu, V., \& Tucmeanu, A. (2014). The Professional vs. the Manager - Identity Issues and Key Features. Valahian Journal of Economic Studies, 5(3), 31-36.

Bureau, S., \& Zander, I. (2014). Entrepreneurship as an art of subversion. Scandinavian Journal of Management, 30(1), 124-133. https://doi.org/10.1016/j.scaman.2013.12.002

Cardon, M. S., Wincent, J., Singh, J., \& Drnovsek, M. (2009). The nature and experience of entrepreneurial passion. Academy of Management Review, 34(3), 511-532. https://doi.org/10.5465/AMR.2009.40633190

Carroll, B., \& Levy, L. (2008). Defaulting to management: Leadership defined by what it is not. Organization, 15(1), 75-96. https://doi.org/10.1177/1350508407084486

Clarke, J. S., \& Holt, R. (2019). Images of entrepreneurship: Using drawing to explore entrepreneurial experience. Journal of Business Venturing Insights, 11(June), 20192021. https://doi.org/10.1016/j.jbvi.2019.e00129

Dahlsen, J. (2015). An environmental artist and PhD candidate's observations of globalism's post GFC aftermath: Is there economic viability, for marginalised artists creating the culture of environmental sustainability?. Developmental Observer, 8(1), 97-131. https://doi.org/10.14434/do.v8i1.27785

Damásio, M. J., \& Bicacro, J. (2017). Entrepreneurship education for film and media arts: How can we teach entrepreneurship to students in the creative disciplines? Industry and Higher Education, 31(4), 253-266. https://doi.org/10.1177/0950422217713110

Davidsson, P. (2006). Nascent Entrepreneurship: Empirical Studies and Developments. Foundations and Trends ${ }^{\circledR}$ in Entrepreneurship, 2(1), 1-76.

Degot, V. (2007). Portrait of the manager as an artist. Aesthesis: International Journal of Art and Aesthetics in Management and Organizational Life, 1(3), 6-42.

Devkota, N., Paudel, U. R., \& Bhandari, U. (2020). Does westernization influence the business culture of a touristic city?. Economics and Sociology, 13(4), 154-172. doi:10.14254/2071-789X.2020/13-4/10

Dufour, L., Maoret, M., \& Montani, F. (2020). Coupling high self-perceived creativity and successful newcomer adjustment in organizations: the role of supervisor trust and support for authentic self-expression. Journal of Management Studies, 57(8), 15311555. https://doi.org/10.1111/joms. 12547

Elstad, B., \& Jansson, D. (2020). From artist to manager - working conditions, career satisfaction, and professional identity among graduated arts management students. Journal of Arts Management Law and Society, 50(3), 184-198. https://doi.org/10.1080/10632921.2020.1746717

Enhuber, M. (2014). How is Damien Hirst a Cultural Entrepreneur? Artivate: A Journal of Entrepreneurship in the Arts, 3(2), 3-20. 
https://repository.asu.edu/attachments/146224/content/Artivate Vol 3 No 2 pages 3-20 Enhuber.pdf

Erat, S., Kitapçi, H., \& Akçin, K. (2020). Managerial perception and organizational identity: A comparative analysis. Sustainability, 12(6), 1-16. https://doi.org/10.3390/su12062278

Gangi, J. (2018). Classical guitar study as creativity training: Potential benefits for managers and entrepreneurs. Journal of Open Innovation: Technology, Market, and Complexity, 4(45), 1-10. https://doi.org/10.3390/joitmc4040045

Gerpott, F. H., Van Quaquebeke, N., Schlamp, S., \& Voelpel, S. C. (2019). An Identity Perspective on Ethical Leadership to Explain Organizational Citizenship Behavior: The Interplay of Follower Moral Identity and Leader Group Prototypicality. Journal of Business Ethics, 156(4), 1063-1078. https://doi.org/10.1007/s10551-017-3625-0

Gray, D. E., Gabriel, Y., \& Goregaokar, H. (2015). Coaching unemployed managers and professionals through the trauma of unemployment: Derailed or undaunted?*. Management Learning, 46(3), 299-316. https://doi.org/10.1177/1350507614532752

Grigoryan, L. K., \& Kotova, M. V. (2018). National identity management strategies: Do they help or hinder adoption of multiculturalism in Russia? Psychology in Russia: State of the Art, 11(3), 18-35. https://doi.org/10.11621/pir.2018.0302

Hallier, J. (2004). Embellishing the past: Middle manager identity and informality in the implementaion of new technology. New Technology, Work and Employment, 19(1), 4362. https://doi.org/10.1111/j.1468-005X.2004.00127.x

Hatch, M. J., Kostera, M., \& Koźmiński, A. K. (2006). The three faces of leadership: Manager, artist, priest. Organizational Dynamics, 35(1), 49-68. https://doi.org/10.1016/j.orgdyn.2005.12.003

Horn, D., \& Salvendy, G. (2009). Measuring consumer perception of product creativity: Impact on satisfaction and purchasability. Human Factors and Ergonomics In Manufacturing, 19(3), 223-240. https://doi.org/10.1002/hfm.20150

Hracs, B. J. (2015). Cultural Intermediaries in the Digital Age: The Case of Independent Musicians and Managers in Toronto. Regional Studies, 49(3), 461-475. https://doi.org/10.1080/00343404.2012.750425

Jankurová, A., Ljudvigová, I., \& Gubová, K. (2017). Research of the nature of leadership activities. Economics and Sociology, 10(1), 135-151. https://doi.org/10.14254/2071789X.2017/10-1/10

Kasmaienezhadfard, S., Talebloo, B., Roustae, R., \& Pourrajab, M. (2015). Students' Learning Through Teaching Creativity: Teachers' Perception. Journal of Educational, Health and Community Psychology, 4(1), 1-13. https://doi.org/10.12928/jehcp.v4i1.3699

Kiran, N., Afzal, M., Hussain, M., \& Gilani, S. A. (2019). Initials Impact of Nursing Manager Perception of Empowerment and Years of Experience on Resistance to Change in Practice. Journal of Health, Medicine and Nursing, 62, 82-89. https://doi.org/10.7176/jhmn/62-11

Kohail, Y., Saida, Y., Obad, J., \& Soulhi, A. (2016). The Qualities of a Good Manager ... What Does It Means? Lessons Learned from the Undergraduate Business Students' Perception in Kingdom of Morocco. International Journal of Business and Management, 11(8), 86-96. https://doi.org/10.5539/ijbm.v11n8p86

Kostiukevych, R., Mishchuk, H., Zhidebekkyzy, A., Nakonieczny, J., \& Akimov, O. (2020). The impact of European integration processes on the investment potential and institutional maturity of rural communities. Economics and Sociology, 13(3), 46-63. doi:10.14254/2071-789X.2020/13-3/3 
Kunrath, K., Cash, P., \& Kleinsmann, M. (2020). Social- and self-perception of designers' professional identity. Journal of Engineering Design, 31(2), 100-126. https://doi.org/10.1080/09544828.2019.1676883

Lähdesmäki, M. (2012). Construction of owner-manager identity in corporate social responsibility discourse. Business Ethics, 21(2), 168-182. https://doi.org/10.1111/j.1467-8608.2011.01644.x

Lehmann, J., \& Gaskins, B. (2019). Learning scientific creativity from the arts. In Palgrave Communications (Vol. 5, Issue 95, pp. 1-5). https://doi.org/10.1057/s41599-019-0308-8

Leso, G., Dias, G., Ferreira, J. P., Gama, J., \& Couceiro, M. S. (2017). Perception of Creativity and Game Intelligence in Soccer. Creativity Research Journal, 29(2), 182187. https://doi.org/10.1080/10400419.2017.1302779

Lewis, K. V., Ho, M., Harris, C., \& Morrison, R. (2016). Becoming an entrepreneur: Opportunities and identity transitions. International Journal of Gender and Entrepreneurship, 8(2), 1-5. https://doi.org/http://dx.doi.org/10.1108/IJGE-02-20150006

López-Fernández, M., Romero-Fernández, P. M., \& Aust, I. (2018). Socially responsible human resource management and employee perception: The influence of manager and line managers. Sustainability (Switzerland), 10(12), 1-19. https://doi.org/10.3390/su10124614

Lord, R. G., \& Brown, D. J. (2001). Leadership, values, and subordinate self-concepts. The Leadership Quarterly, 12, 133-152.

Lutas, M., Nistor, R., Radu, M., \& Beleiu, I. (2020). Perceptions regarding the profile of an ideal project manager. Amfiteatru Economic, 22(54), 608-622. https://doi.org/10.24818/EA/2020/54/608

Masso, A. (2010). Geographical perspective on identity construction: Identification strategies of Russian youth in Estonia. International Journal of Interdisciplinary Social Sciences, 5(6), 51-62. https://doi.org/10.18848/1833-1882/CGP/v05i06/51763

McHugh, K. E. (2015). Touch at a distance: toward a phenomenology of film. GeoJournal, 80(6), 839-851. https://doi.org/10.1007/s10708-015-9650-6

McNeill, L., \& Venter, B. (2019). Identity, self-concept and young women's engagement with collaborative, sustainable fashion consumption models. International Journal of Consumer Studies, 43(4), 368-378. https://doi.org/10.1111/ijcs.12516

Naderi, H., Abdullah, R., Aizan, H. T., Sharir, J., \& Mallan, V. K. (2009). Gender differences in creative perceptions of undergraduate students. Journal of Applied Sciences, 9(1), 167-172. https://doi.org/10.3923/jas.2009.167.172

Nikolski, K. (2015). Leadership and Management: Practice of the Art of Influence. Annals of the ,Constantin Brâncuşi” University of Târgu Jiu, Economy Series, 2(1), 31-39.

Nowak, S. (2007). Metodologia Badań Społecznych. In Metodologia Badań Społecznych. Wydawnictwo Naukowe PWN.

Okuneviciute Neverauskiene, L., \& Pranskeviciute, I. (2021). Hybridity of social enterprise models and ecosystems. Journal of International Studies, 14(1), 41-59. doi:10.14254/2071-8330.2021/14-1/3

Postuła, A., \& Majczyk, J. (2018). Managers and leaders in need of entrepreneurial competences. Entrepreneurial Business and Economics Review, 6(1), 91-103. https://doi.org/10.15678/EBER.2018.060105

Raso, R., Fitzpatrick, J. J., \& Masick, K. (2020). Clinical nurses' perceptions of authentic nurse leadership and healthy work environment. Journal of Nursing Administration, 50(9), 489-494. https://doi.org/10.1097/NNA.0000000000000921 
Reedy, P. (2008). Mirror, mirror, on the wall: Reflecting on the ethics and effects of a collective critical management studies identity project. Management Learning, 39(1), 57-72. https://doi.org/10.1177/1350507607085978

Saavedra Llamas, M., \& Grijalba de la Calle, N. (2020). The creative cinematographic process at the service of national identity: Pedro Almodóvar and the promotion of Spanish stereotypes. Creativity Studies, 13(2), 369-386. https://doi.org/10.3846/cs.2020.8563

Schielke, T. (2020). Interpreting Art with Light: Museum Lighting between Objectivity and Hyperrealism. LEUKOS - Journal of Illuminating Engineering Society of North America, 16(1), 7-24. https://doi.org/10.1080/15502724.2018.1530123

Sethi, A., Mishra, N., \& Dash, M. (2012). Social Identity Crisis Amongst Employees in Mergers \& Acquisitions. SSRN Electronic Journal, 244-263. https://doi.org/10.2139/ssrn.1588565

Stuke, K. B. (2013). Understanding Leadership Through Leadership Understandings. Journal of Leadership Studies, 7(2), 55-61. https://doi.org/10.1002/jls.21291

Sveningsson, S., \& Alvesson, M. (2003). Managing managerial identities: Organizational fragmentation, discourse and identity struggle. Human Relations, 56(10), 1163-1193. https://doi.org/10.1177/00187267035610001

Szczepaniak, K. (2018). Arts for Business: Creative Co-operation for Innovation and Sustainable Development of the Company as a Brand and Community. Kwartalnik $\begin{array}{llll}\text { Ekonomistów } i & \text { Menedżerów, } & \text { 50(4), }\end{array}$ https://doi.org/10.5604/01.3001.0013.0639

Szostak, M. (2020). Creativity and Artistry in Organ Music. The Organ, 391, 24-31. https://depot.ceon.pl/handle/123456789/19170

Szostak, M., \& Sułkowski, Ł. (2020a). Manager as an artist: Creative endeavour in crossing the borders of art and organizational discourse. Creativity Studies, 13(2), 351-368. https://doi.org/10.3846/cs.2020.11373

Szostak, M., \& Sułkowski, Ł. (2020b). Kitsch in Management: characteristic forms, carriers and propagators. Education Excellence and Innovation Management: A 2025 Vision to Sustain Economic Development during Global Challenges: Proceedings of the 35th International Business Information Management Association Conference (IBIMA), 1-2 April 2020, 7584-7598. https://www.researchgate.net/publication/345996764_Kitsch_in_Management_characte ristic_forms_carriers_and_propagators

Taleghani, M. (2012). Impact of Attitudes on Managers Creativity. Procedia - Social and Behavioral Sciences, 40, 65-70. https://doi.org/10.1016/j.sbspro.2012.03.162

Tendayi Viki, G., \& Williams, M. L. J. (2014). The role of identity integration in enhancing creativity among mixed-race individuals. Journal of Creative Behavior, 48(3), 198-208. https://doi.org/10.1002/jocb.48

Toscher, B. (2019). Entrepreneurial Learning in Arts Entrepreneurship Education: A Conceptual Framework. Arti, 8(1), 3-22.

Toscher, B. (2020). Blank Canvas: Explorative Behavior and Personal Agency in Arts Entrepreneurship Education. Artivate: A Journal of Entrepreneurship in the Arts, 9(2), 19-44. https://doi.org/10.34053/artivate.9.2.115

Vincent, L. C., \& Kouchaki, M. (2016). Creative, rare, entitled, and dishonest: How commonality of creativity in one's group decreases an individual's entitlement and dishonesty. Academy of Management Journal, 59(4), 1451-1473. https://doi.org/10.5465/amj.2014.1109

Walter, H. M. (2015). Artist, Professional, Gentleman: Designing the Body of the ActorManager, 1870-1900. Royal College of Art. 
Warhurst, R. (2011). Managers' practice and managers' learning as identity formation: Reassessing the mba contribution. Management Learning, 42(3), 261-278. https://doi.org/10.1177/1350507610387567

Watson, T. J. (2009). Narrative, life story and manager identity: A case study in autobiographical identity work. Human Relations, 62(3), 425-452. https://doi.org/10.1177/0018726708101044

Wilson, C., \& Brown, M. (2012). Sound, space, image and music: Hybridity in creative process through technology, interactivity and collaboration. Journal of Music, Technology and Education, 5(1), 89-107. https://doi.org/10.1386/jmte.5.1.89_1

Wimschneider, C., \& Brem, A. (2019). The perception of creativity through multicultural experience -results from an empirical analysis. International Journal of Innovation Management, 23(7). https://doi.org/10.1142/S1363919619500658

Wolf, C. (2019). Not lost in translation: Managerial career narratives and the construction of protean identities. Human Relations, 72(3), 505-533. https://doi.org/10.1177/0018726718778094

Woodward, J. B., \& Funk, C. (2010). Developing the artist-leader. Leadership, 6(3), 295-309. https://doi.org/10.1177/1742715010368768

Yazar, T., \& Arifoglu, G. (2012). A Research of Audio Visual Educational Aids on the Creativity Levels of 4-14 Year Old Children as a Process in Primary Education. Procedia - Social and Behavioral Sciences, 51, 301-306. https://doi.org/10.1016/j.sbspro.2012.08.163

Zambrell, K. (2016). Managers' identity construction at work: Artistic interventions as triggers for identity work. Organizational Aesthetics, 5(2), 34-67.

Zhou, J., Shin, S. J., \& Cannella, A. A. (2008). Employee self-perceived creativity after mergers and acquisitions: Interactive effects of threatĝ $€$ "opportunity perception, access to resources, and support for creativity. Journal of Applied Behavioral Science, 44(4), 397-421. https://doi.org/10.1177/0021886308328010

Zocche, L., de Paula, I. C., Kunrath, S. E., Martins, V. L. M., \& Lermen, F. H. (2018). Variables that influence creativity in perception of professionals: A case study in innovative Brazilian companies. Thinking Skills and Creativity, 29, 170-184. https://doi.org/10.1016/j.tsc.2018.07.002 